\title{
PRAGMATIC ORGANIZATION OF MEDICAL SPELLS IN THE ENGLISH AND FRENCH LANGUAGES
}

\author{
Oleksandra Palchevska
}

PhD. Associate Professor, Lviv State University of Life Safety, Ukraine e-mail: palch56@ukr.net,orcid.org/0000-0002-2090-4870

\section{Viktoriia Shabunina}

PhD. Associate Professor, Taras Shevchenko National University of Kyiv, Ukraine e-mail: vshabunina@gmail.com,orcid.org/0000-0002-8818-1541

\section{Oksana Labenko}

$\mathrm{PhD}$. Tutor, Taras Shevchenko National University of Kyiv, Ukraine e-mail: o.v.labenko@gmail.com,orcid.org/0000-0002-5335-3331

\section{Summary}

The article presents communicative and pragmatic models of implementation of the concept disease in the medical incantation. Linguopragmatics as a field of modern linguistics is certainly one of the closest to cultural studies, and to some extent even overlaps in its content with it and studies the language in its real, situational, personal, localized time and space functioning, in the context of behavior, communication of its subjects, addressees, content, goals, etc. It has been proved that sacred texts, which include incantation, are largely "communicative". In such texts there is a clearly expressed goal (to exile, frighten or wheedle the disease, to transfer it from the patient to the tree, to the subject, etc.) and a very specific addressee (this may be the disease itself, the sick, the demon, the saint, the go-between, God, etc.). They usually contain clear pragmatic organization, correlation with a certain situation - indications on the transmitter, the addressee, the illocutionary purpose (vocatives, pronouns of 1 and 2 persons, imperatives, optative formulas), and their general ritual semantics is determined by the primary (internal) pragmatic guideline. It can be argued that the addresser of medical incantation is a versatile phenomenon, both in terms of pragmatic models and functions, and the ethnic and social peculiarity prevailing over these functions. Most often the role of the addresser acts as a person who heals applying magic formulas that are additional or primary in the medical practice. Sometimes the addresser is the patient himself.

There are three types of addressees in all studied languages: 1) about direct addressee of the ceremonial situation, that is, about one of the participants of the ritual to which the text is referred (for example, the patient in the ritual of treatment), 2) about the addressee marked and named in the text (it might not be only a real ceremonial person, but also God, a holy, personified holiday, demonological character, object, object or instrument of action), 3) about some absolute addressee, the higher power to which ultimately appeals any ritual text of any incantation.

Keywords: folk picture of the world, linguopragmatics, pragmatic organization, medical spells, addresser, addressee.

\section{DOI: https://doi.org/10.23856/3852}

\section{Introduction}

One of the closest to the cultural studies modern linguistics field is certainly linguistic pragmatics, which to some extent even intersects with its content and studies the language in its real, situational, personal, localized in time and space functioning, in the context of behavior as well as of its subjects, addressees, content, goals, communication etc. 
It is believed that the texts of the spells are largely "communicative" (Wilson, 2000).

Such texts clearly state the purpose (to banish, frighten, or cure the disease, transfer it from the patient to the tree, to the subject, etc.). and a very specific addressee (it may be the disease itself, the sick, the demon, the saint, the mediator, God, etc.) (Tolstaya, 2010, p. 198).

In many cases ceremonial texts (songs, sayings, spells, etc.) or fragments of them are pragmatically marked and act in their essence as requests, supplications, wishes, orders, promises, invitations, threats, curses, questions, greetings. They usually contain clear signs of pragmatic organization, that is, the correlation with a situation - the addresser, the addressee, the illocutionary purpose (vocatives, 1 and 2 person pronouns, imperatives, optative formulas), and their general ritual semantics is determined with primary (internal) pragmatic guidelines.

\section{The illocutionary aim of the medical spell ceremonial text}

The basic starting point of the speech acts theory, created by J. Austin, is the language, or an illocutionary act. This theory was introduced into the scientific use by J. Sermelio, who defines the speech act itself as the minimum unit of linguistic communication (Searle, 1986, p. 172).

The implementation of a speech act by J. Austin contains the following components: 1) the pronunciation of clear sounds that belong to a common language code; 2) constructing the utterance from the particular language words in accordance with its the grammar rules; 3) implementation of the "speaking" process, while the utterance must be given common sense and reference; 4) the expression of a communicative purpose in the process of pronouncing the utterance, the implementation of an illocutionary act; 5) creation of a certain further influence on the listener's thoughts, feelings or actions, the implementation of a perlocutionary act (See Berdnikova, 2005, p. 19).

Significant for our study is the statement of V.G. Admons about the unity of speech act and speech genre features. The scientist notes that such unity manifests itself in the ability to express the same illocutionary purpose in different linguistic means, forming different variants of the same act/genre, respectively. Possible linguistic variants are organized into a kind of a field that has a center and a periphery. The center stands for the most common and most anticipated implementations of the act/genre, the periphery - all other variants, including expressive and rare ones (archaic, dialect, slang). The text segment implies the textual realization of a certain illocutionary purpose, characterized by different length, genre correlation, unity of the theme and presence of coherence linguistic and illocutionary elements. It can be a sentence, a paragraph (phrase unity), a replica, or a combination of several dialogues (dialog phrases) (Admons, 1964, p. 49).

The study of expression as a purposeful linguistic act is one of the main tasks of modern pragmatics (Dake, 1978). The illocutionary purpose of the speaker's expression, the linguistic ways of its embodiment, and the communication implications (Gritsenko, 1986), which are the key to successful communication, are taken into account.

In terms of O.O. Selivanova's illocutionary force is the implicit or explicit intention of the addressee as a speech act function (Selivanova, 2006, p. 320). Illocutionary purpose is the main part of the illocutionary force that does not exhaust it. Yes, the illocutionary purpose of requests and orders is the same: they are an attempt to induce an interlocutor to do something, and their illocutionary forces do not coincide. This gives reason to consider illocutionary power as a partial case of a much broader and more general phenomenon - the speaker' intention and the related concepts. It is obvious that the speaker uses not only illocutionary markers (means of expressing illocution) but also many others (presupposition, metaphor, rhetorical techniques, etc.) to achieve his goal. 
The concept of the illocutionary purpose of the ritual text is ambiguous and multifaceted. The target, like the destination, has several models. This may be a literal, straightforward goal, expressed in the text and predetermined by its form (for example, wishful thinking), an intrinsic goal (for example, receiving a reward for the sake of goodwill or for the performance of carols), a more distant goal (providing for a crop, breeding cattle, healing from illness, protecting from evil forces) and, finally, some higher purpose (preservation of universal well-being and world order).

The most striking feature of the ritual folklore text pragmatics is its principled "perlocution", mediocrity, divergence of the literal, direct meaning of what is said (its logical, propositional content) with what is "implied", for illicit purposes. In this case, the secondary, indirect meanings and purposes of the utterance are conventionally assigned, proposed and predetermined structure and purpose of the rite and text. They do not depend on the will of the text executor (Selivanova, 2010, p. 200).

The main task at the same time is to discover what is called the "linguistic design" or "the speaker' linguistic will" and what in the theory of language acts is called illocutionary purpose. The same text that contains the stripping semantics can "bring to the fore" the carrier of the danger in various ways: by means of threat, request, order, etc. In each case, the "linguistic will" of the speaker will be fulfilled and will also meet a certain illocutionary purpose of threat, request, order.

Illocutionary purpose of expressing the order in the medical text is healing and is expressed by certain lexical and grammatical means or their totality in the structure of expression.

\section{The addresser in the medical spell}

The addresser in the spell is the person who performs the ritual, the one who pronounces the text of the spell. The addresser can usually be represented in the text of the spell implicitly or explicitly. In cases where the patient pronounces the spell by himself, acts as the customer, the addressee is verbally expressed by means of the first-person pronouns "I", "We" and / or the corresponding verb form.

For the English linguistic culture the refer to the people treated (including spells) is characterized by the use of the names bonesetter, midwive, dentist, leech woman (Marland, Hilary, 1987, p. 214-228), in addition there are nominations white which, folk heeler.

In French linguoculture, the following nominations are found to denote the person who heals: panseur de secret - the "spellcaster" - the one who heals spells, that is, uses secret - secret words, which causes the supernatural forces to obey and interfere accordingly. These words are mostly devoid of content (were thought to have incomprehensibility the greatest effect on the patient), often used alliteration, to give special solemnity to the process of the spell. There are more such names as: flotteur, le menieur rouge, metze, laboureux, vertaipier, rebouteur, maige, guérisseur, gougneux, la bonne femme guérisseuse (Ramsey, 1988, c. 240-253). All of these nominations differ in their semantics, in terms of the specificity of treatment, the common use of magical formulas or orders in medical practices of folk healers.

When a sick person has to say thespell him or herself, it is very often stated in the instructions to it:

Engl. "Shetland. Ringworm.-The person afflicted with ringworm takes a little ashes between the forefinger and thumb, three successive mornings, and before having taken any food and holding the ashes to the part affected, says: 
"Ringworm! ringworm red!...." At the same time, throwing the little ashes held between the forefinger and thumb into the fire".

The person of the addresser may be determined by the genre specificity of the spell, such as in children's sayings-spells: "Louth. Dock. - A name applied to all our native Rumex. ... Children used to apply Docken leaves to their hands after having been stung by nettles, saying "Docken go in, nettle come out"”; "Nettle stings. - Docken or Dockin is the name given to the common dockweed which is used as an antidote. Children rub the part, saying," Nettle oot, Dockin in."; "Tooth-lore. - In the East Riding they eat sugar when a tooth is pulled out, and throw the tooth into the fire, saying Fire, fire, here's a bone, Pray God send a tooth again".

Sometimes person of the addresser is indicated by the pronoun:

Engl. "Ashen tree, ashen tree,

Pray buy these warts of me".

"Jesus Christ, that died upon the

cross, put my warts away...”.

"In the name of God, on Mount Olivet

First I thee found;

In the name of Jesus

Ipull thee from the ground".

"In Kent, if a man wets his forefinger with saliva, and rubs the wart he wishes to get rid of three times in the same direction as a passing funeral, saying each time (without any of the ceremony above observed) "My wart goes with you," a cure will soon follow".

Fr. "Nettoie-moi bien, fraîche rosée

sens comme je suis galeux

vois combien se trouve entaché

mon corps des pieds à la tête etc.

Veuille bien me débarasser

Dans cette avoine;

Car si tu fais que bientôt je me guérisse-

Nuit et jour je vais te bénir;

"Je ne ferai rien qui ne soit à faire, s'il plait à Dieu. Au nom de Dieu et de la sainte Vierge, si c'est l'ongle, que Dieu le décombre; si c'est le dragon, que Dieu le confonde; si c 'est le vent, que Dieu le commande!".

It is observed that the addresser may be implicitly labeled, that is, verbalized in the instructions to the order:

"Whooping-Cough. - This common enemy of childhood has, from time immemorial, afflicted ample opportunity to the superstitiously-inclined to devise sundry charms for its cure, of which the following area few: - Passing the patient three times under the belly and three times over the back of a donkey; or let the parent of the afflicted child catch a spider, and hold it over the head of the child, repeating three times: - "Spider, as you waste away, Whooping-cough no longer stay"; "Set thy mind well upon God and say these words thrice in his ear-Anamzapta".

The peculiarity of the French spell is that the instruction is included in the spell text:

"Quand Pierre et Simon

Montaient les monts,

Simon s'assit;

Notre-Seigneur lui dit: - Que fais-tu là, Simon?

- Oh! mon Seigneur, je suis

Si malade du mal des fonds 
Que je ne puis

Monter les monts.

- Lève-toi, lève-toi, Simon

Quand tu auras dit

Trois fois cette oraison.

Tu seras guéri

Du mal des fonds";

"Saint Pierre sur le pont de Dieu s'assit.

Notre-Dame de Caly vint et lui dit :

- Pierre, que fais-tu là ? - Dame, c'est pour le mal

De mon chef que je me suis mis là.

- Saint Pierre, tu te leveras,

A Saint-Agie tu t'en iras ;

Tu prendras le saint onguent

Des plaies mortelles de Notre-Seigneur,

Tut'en graisseras,

Et trois fois tu diras:

"Jésus, Maria.".

The addresser's social status may determine the course of the illness. Just like spellngs from malaria or swamp fever, a prerequisite for a successful spell is that it should be spoken by the oldest woman in the family: "Another charm for ague was directed to be said up the chimney, by the eldest female of the family, on St. Agnus Eve. It ran thus: Tremble and go!...".

The same is observed in the magical-verbal medical practices of treating scrofula, which, according to British traditions, was treated by the laying on of the royal person's hand or of the hand of a murderer, a dead man, or a virgin girl. The same person should have said the order: "Scrofula. For this disease many charms have been employed, but no remedy has been so highly esteemed as the royal touch, of which a particular history is oiven in another part of this volume. The hand of the sovereign, however, was by some deemed not more efficacious than that of a murderer or of a virgin; for in Scot's 'Discovery of Witchcraft' it is stated, "To heal the king or queen's evil, or any other soreness of the throat, first touch the place with the hand of one that died an untimely death, otherwise let a virgin, fasting, lay her hand on the sore, and say, "Apollo denyeth that the heat of the plague can increase where a naked virgin quencheth it; ' and spit three times upon it" (onsuperstitions, c. 107).

The addresser's qualification as well as the manner of pronouncing the spell are a prerequisite for the treatment of certain diseases: "Shetland. When a person has received a sprain, it is customary to apply to an individual practised in casting the 'wresting thread.' This is a thread spun from black wool, on which are cast nine knots, and tied round a sprained leg or arm. During the time the operator is putting the thread round the affected limb, he says, but in such a tone of voice as not to be heard by the bystanders, nor even by the person operated upon: "The Lord rade, And the foal slade...."; "Nightmare Charm or Spell against the Mara, - Pulling from my head the longest hair it possessed, and then going through the pantomime of binding a refractory animal, (the nurse) slowly chanted this spell: "De man o' meicht..."; "Stemming blood.-For suppressing hemorrhage, as spitting of blood, bleeding from the nose, bleeding from a wound, the following charm is solemnly repeated once, twice, or oftener, according to the urgency of the case, by some old man or woman accounted more sagacious than their neighbours. It is not to be repeated aloud, nor in the presence of any one but the patient "Three Virgins came across Jordan Sand... "; "What would the grandmothers say if they could return 
and see the spoiling of Hob's dwelling-place: whose aid they used to invoke for the cure of whooping-cough. - Standing at the entrance of the cave with the sick child in their arms, they addressed him thus Hob-hole Hob!... "”.

\section{Conclusions and suggestions}

So we can state that the illocutionary purpose of the medical spell text $\mathrm{o}$ is healing and is expressed by certain lexical and grammatical means or their totality in the structure of expression.

Medical spell is a complicated phenomenon both in terms of pragmatic models and functions, and in terms of ethnic and social specificity, which dominates these functions. Most often, the addresser is the person treating using magic formulas in his practice and they may be additional or primary in medical practice. Sometimes the patient is the addresser.

The model of the addressee in the medical spell text is complex. There are three types of addressees: 1) the direct addressee of the ritual situation, that is, one of the participants in the rite to which the text is directed (for example, the patient in the healing ritual), 2) the addressee, marked and named in the text itself (this may not only be a real ritual person, but also God, holy, personified holiday, demonological character, object or instrument of the action), 3) some absolute addressee, that is, the higher power, to which ultimately any ritual text of a spellbinding nature appeals.

The spell has a clear structure. You can talk about the beginning, the main part and the conclusion. Conversion formulas are one of the central functions of medical spells and are divided into several semantic types, distributed according to certain functional models.

\section{References}

Admoni, V. G. (1964). Fundamentals of Grammar Theory. L. : Science.

Berdnikova, A. G. (2005). Gratitude: Cognitive and semantic-pragmatic aspects: diss. ... the candidate of filol. sciences: 10.02.01. Novosibirsk.

Dijk, T. A. (1978). Questions of text pragmatics. New in foreign linguistics. M. : Progress, Iss. 8. Linguistics of the text. Pp. 259-336.

Gritsenko, P. Yu. (1984). Modeling of the system of dialect vocabulary. K. : Scientific thought. Marland, Hilary. (1987). Medicine and Society in Wakefield and Huddersfield, 1780-1870. Cambridge: Cambridge University Press.

Ramsey, Matthew (1988). Professional and Popular Medicine in France 1770-1830: The Social World of Medical Practice. Cambridge : Cambridge University Press.

Ramsey, Matthew (1988). Professional and Popular Medicine in France 1770-1830: The Social World of Medical Practice. Cambridge: Cambridge University Press.

Searle, J. (1986). Classification of illocutionary acts. New in foreign linguistics. Issue 17: Theory of speech acts. M. : Pp. 170-194.

Selivanova, E.A. (2004). Osnovyi lingvisticheskoy teorii teksta i kommunikatsii. [Fundamentals of linguistic theory of text and communication]. Kyiv [in Ukrainian].

Selivanova, O. O. (2010). Linguistic Encyclopedia. Poltava : Environment-K.

Tolstaya, S. M. (2010). Semantic categories of the language of culture: Essays on Slavic ethnolinguistics. M. : LIBROCOM. 